\title{
Building Health Parameters and Willingness to Pay of Residents In Jakande Estate, Lagos, Nigeria
}

\author{
Adelabu, T. A, Olanrewaju , S.O and Ige, V.A
}

\begin{abstract}
It is against the background of the intricate relationship between condition of housing, health and affordability of residents that this study investigates housing health conditions and willingness to pay of residents on Jakande Estate, Lagos, Nigeria. This is with view of proffering recommendations that will aid the achievement of affordable healthy buildings in the area. To achieve this, 340 housing units were sampled using a random systematic sampling technique at an interval of every third house in all the streets in the estate. Questionnaire was then administered to the household head of each sampled building. Obtained information such as income, annual rent, willingness to pay (WTP) and perceived satisfaction with housing parameters were subjected to descriptive statistics such as percentages. Also, Likert rating of W'TP was done to assess the willingness of residents to pay for building health parameters. It was observed that about $87 \%$ of the residents of the estate are civil servants, while about $45 \%$ of them earn a monthly income between $50,000-100,00$. Also, $62 \%$ of the residents pay a moderate rental value of $100,000-$ 150,000. Residents are willing to pay as high as 30,000 annually for good water (3.5), cross ventilation (2.91) and good ceiling (2.81). However, about $60 \%$ of the residents are not satisfied with the level of noise in the estate. Also, about $65 \%$ are not satisfied with water and sanitation. The study therefore recommends provision of central boreholes, employment of sanitation workers and community participation for the achievement of affordable healthy buildings in the estate.
\end{abstract}

Keywords: Housing, Building Health, Willingness to pay, Rental value, Community Participation

\section{Introduction}

Residential property is a multi-dimensional commodity, characterized by durability, structural inflexibility and spatial fixity. However, every residential unit has its unique bundle of attribute such as proximity, transport, amenities, structural efficiency, neighbourhood, and environmental quality [1, 2 and 3]. These attributes for any housing unitswithin any neighbourhood should be such that satisfies

\footnotetext{
Adelabu, T. A (Department of Estate Management, Wesley University, Ondo, Nigeria)

Olanrewaju , S.O (Department of Urban and Regional Planning, KSUST, Aliero, Nigeria)

Ige, V.A Department of Urban and Regional Planning, Crown Polytechnic, Ado-Ekiti, Nigeria)

Corresponding author: olanrewajusamson9@gmail.com ,

Phone Number:+2347038540456)
}

minimum health standards and good living, and be affordable to all categories of households [4]. By implication, a healthy building is a built environment that encourages positive well-being of its occupants $[5,6]$.

As suggested in the literature, the exact relationship between housing and health is complex and difficult to assess [7]. Despite this, [8] reported that poor housing is associated with risk of cardiovascular diseases, while housing features such as structure of shelter, water supplies, sanitation and waste disposal have both direct and indirect effects on its users $[9,10]$. Also, studies in developed countries reveals that people spend more than $90 \%$ of their time in their various homesbecause of its psychological importance as an object of 
attachment, a source of identity, and a refuge from stress [11]. However, very few people can afford the kind of housing quality that meets their health needs; therefore, economic situation may force people to accept poor quality housing, even if it is detrimental to their health [12].

After the outbreak of cholera and Tuberculosis in different parts of Africa, SARS in Asia, which claimed about 300 lives in Hong Kong alone in 2003 and Ebola virus in some parts of Africa, healthy living environment became a major concern that called for focused studies in many countries. However, since this period, in-depth studies particularly investigating the nexus between housing and health have placed emphasis on developed countries like Australia, Britain, United States of America and so on [10]. It is against this background that this study aims to evaluate building parameters and willingness to pay for healthy housing by residents in Jakande Estate of Lagos State, Nigeria. This is with a view to profferingrecommendations that will aid in the achievement of affordable healthy housing in the area and others with similarphysical and socioeconomic characteristics.

\section{The Study Area (Jakande Estate Ipaja)}

Jakande Estate Abesan, is a Low-Income Housing Estatelocated along Ipaja road, off Lagos-Abeokuta express way (Figure 1). It is an estate built primarily for public servants, and has been in existence for over 30years. The estate has a total of 4,272 housing units, comprising two and three-bedroom apartments. The designof the housing units is quite simple, and factored by the low-costpurpose of the estate.

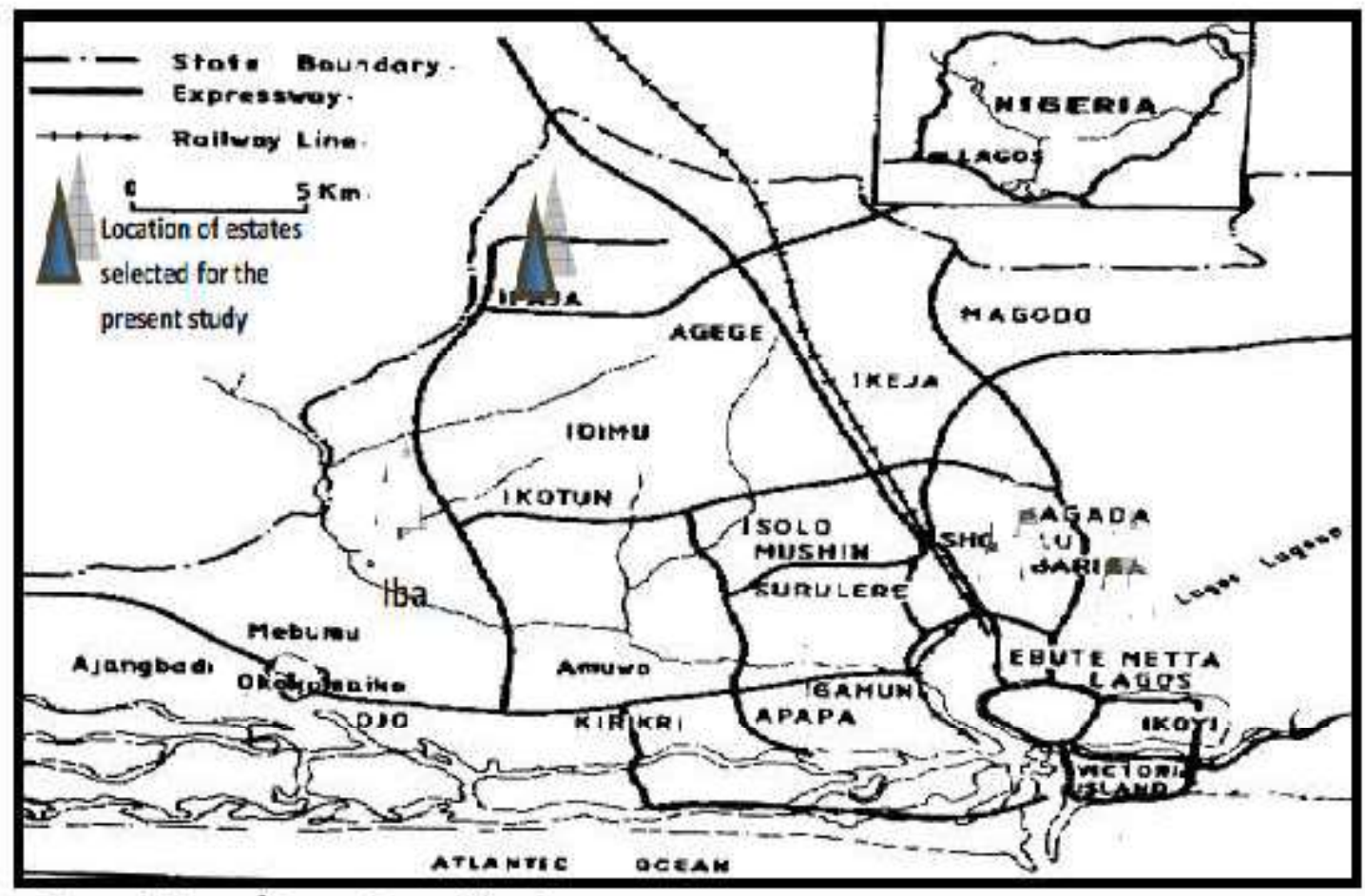

Figure 1: Map of Lagos state showing the study area Source: Adapted from Adebayo and Iweka, 2013 


\section{Methodology}

For this study,both primary and secondary data were employed. Primary data, such as income of respondents, annual rent and type of residential property were obtained with the aid of questionnaire while focused interviewwas also utilised. Secondary data on housing and Lagos state were obtained fromrelevant texts, journals, official documents and gazette. Using a random systematic sampling technique, 340 housing units, $10 \%$ of the entire residential buildings in the estate, were sampled at an interval of every 10th house in a street, where the first house was selected randomly. In each sampled building, questionnaire was administered to a representative (a household head). Data obtained were subjected to descriptive statistics. Descriptive statistics utilised for the study include measure of averages and dispersion.Charts were also used to summarise data set.

\section{Discussion of Findings}

\section{A. Socioeconomic Characteristics of the Respondents}

The socioeconomic attributes of an individual are factors in decision making of such an individual. Authors such as [11, 12] in their different studies maintained that there is a relationship between socioeconomic characteristics of individuals and respondents such as income and age and their choice and perception. Thrusting on this position, the socioeconomic characteristics considered in this paper, among others, include age, income occupation, and the number of years spent in the present location.
Table 1: Socioeconomic Characteristics of

Respondents

\begin{tabular}{|c|c|c|}
\hline Variable & Options & Percentage \\
\hline \multirow[t]{3}{*}{ Sex } & Male & $60.3 \%$ \\
\hline & Female & $39.7 \%$ \\
\hline & Total & $100.0 \%$ \\
\hline \multirow[t]{6}{*}{ Age } & $18-25$ years & $15.0 \%$ \\
\hline & $26-35$ years & $26.0 \%$ \\
\hline & $36-45$ years & $23.5 \%$ \\
\hline & $46-55$ years & $21.2 \%$ \\
\hline & Above 55 years & $15.3 \%$ \\
\hline & Total & $100 \%$ \\
\hline \multirow[t]{5}{*}{ Marital Status } & Single & $20.0 \%$ \\
\hline & Married & $71.0 \%$ \\
\hline & Widow & $7.2 \%$ \\
\hline & Divorced & $2.3 \%$ \\
\hline & Total & $100 \%$ \\
\hline \multirow[t]{5}{*}{ Occupation } & Student & $4.5 \%$ \\
\hline & Civil Servant & $86.5 \%$ \\
\hline & Trader & $5.0 \%$ \\
\hline & Unemployed & $5.0 \%$ \\
\hline & Total & $100 \%$ \\
\hline \multirow[t]{7}{*}{ Income } & Less than 18,000 & $5.3 \%$ \\
\hline & $18,001-30,000$ & $6.4 \%$ \\
\hline & $30,001-50,000$ & $19.2 \%$ \\
\hline & $50,001-100,000$ & $45.0 \%$ \\
\hline & $100,001-150,000$ & $20.0 \%$ \\
\hline & Above 150,000 & $10.2 \%$ \\
\hline & Total & $100 \%$ \\
\hline \multirow[t]{6}{*}{ Annual Rent } & Less than 100,000 & $10.2 \%$ \\
\hline & $100,000-150,000$ & $62.0 \%$ \\
\hline & $150,001-200,000$ & $2.0 \%$ \\
\hline & $200,001-250,000$ & $12.3 \%$ \\
\hline & Above 250,000 & $13.5 \%$ \\
\hline & Total & $100 \%$ \\
\hline Numbers of & $0-2$ years & $5.2 \%$ \\
\hline Years Spent in & $3-5$ years & $29.0 \%$ \\
\hline Current & $6-8$ years & $31.0 \%$ \\
\hline \multirow[t]{3}{*}{ Location } & $9-11$ years & $35.3 \%$ \\
\hline & Above 11 years & $10.5 \%$ \\
\hline & Total & $100 \%$ \\
\hline House & Landlord & $84.6 \%$ \\
\hline \multirow[t]{4}{*}{ Ownership } & Tenants & $12.0 \%$ \\
\hline & Squatters & $3.4 \%$ \\
\hline & Inherited & $0 \%$ \\
\hline & Total & $100 \%$ \\
\hline
\end{tabular}

As revealed in Table 1,about $60.3 \%$ of the respondents are males while $39.7 \%$ are females. This statistic reveals the male dominating nature of issues bothering on housing. The cultural belief in Nigeria that men are the head of the family is reflected on their catering of housing for family members. As a government quarters with this statistics there is likelihood that the estates would have been acquired by men, who in-turn bring in their family members. Also evident in the table is the youthful characteristics of the respondents, where about $26 \%$ are 
between the age range of $26-35$ years, $21.2 \%$ are between the age ranges of $46-55$ years.

Though there are relatively aged individuals in the estate, but it can be concluded that the estate is characterised with youthful population. A youthful adult for the purpose of this paper, are those within the age range of 25 years to 40 years. This category of individuals is not only agile and highly mobile; they have high housing requirements for taste and class. Hence, their demand for healthy accommodation cannot be under estimated.This need is more than necessary as about $71 \%$ of the respondents are married thus will be keen at raising children in healthy buildings. The environmentalcondition, drainage facilities, toilet and sewerage system need of married individuals, especially those at child bearing stage are high.

The residential estate is a civil servant estate, as about $87 \%$ of its residents are civil servants. Thus, these set of individuals will not be fully available during weekdays but at weekends and will require a healthy living environment to compensate for their week-long stress and disturbances. Although there are traders (5.0\%) and students $(4.5 \%)$ in the estate but their proportion is extremely low (Table 1). From the foregoing, one may posit that the estate fulfils one of its purposes of housing civil servants in Lagos, who are considered to be low and middle income earners. This is further testified in Table 1 , as about $45 \%$ of the respondents earn between \#50, 000 - \#100, 000 monthly, while only 10.2\% earn above \# 150,000 monthly. Such a low monthly income could have influenced the decision of the residents to opt for low income housing such as housing estates.

The rental value of housing units in the estate is observed to be relatively moderate compared to rental value of housing units in other locations.
For instance, the rental value of a 2-bedroom apartment in Ipaja is about \#250,000 per annum, while thesame goes for about \#300,000 in Egbeda. However, majority $(62 \%)$ of the housing units, which are basically threebedroom and two-bedroom apartments cost between \#100,000 to \#150,000 per annum. Although various factors such as condition of building, environmental factors and speculation would have accounted for variation in price in the estate [13], yet $10.2 \%$ of the respondents pay less than \#100,000 as annual rent.

As evident in Table 1 , about $84 \%$ of the respondents are landlords whilealow percentage of $12 \%$ are tenants. Also, about $45 \%$ of respondents have been staying in the estate for over 9 yearswhile about $5.2 \%$ of the residents are relatively new. This indicates a low level of

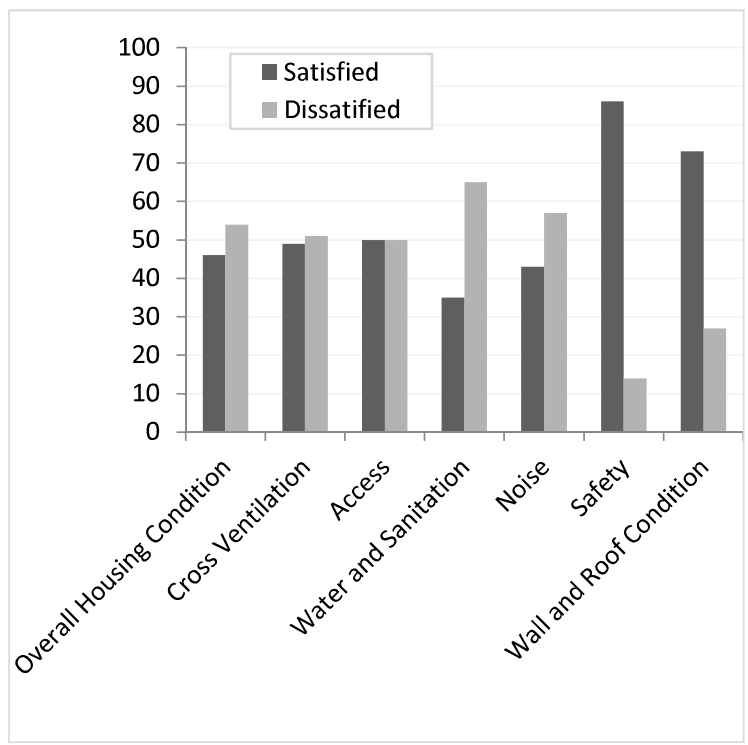

Figure 1: Level of Satisfaction with Housing Parameters in Jakande Estate

immigration in the estate, and suggesting that residents in the study area are either comfortable with the structural characteristics of the housing units in the estate, or unable to change their choice of accommodation for reasons which 
Table 2: Willingness to Pay (WTP) for Healthy Features in Jakande Estate

\begin{tabular}{|c|c|c|c|c|c|c|}
\hline \multirow[b]{2}{*}{ Factors } & \multicolumn{6}{|c|}{ Frequency(percent) } \\
\hline & $\begin{array}{l}5,000-10,000 \\
(1 \mathrm{pt})\end{array}$ & $\begin{array}{l}10,001-20,000 \\
\text { (2pts) }\end{array}$ & $\begin{array}{l}20,001-30,000 \\
\text { (3pts) }\end{array}$ & $\begin{array}{l}30,001 \text { and above } \\
(4 \mathrm{pts})\end{array}$ & Mean Score & Rank \\
\hline Wide and multiple windows & $3(1.0)$ & $97(32.0)$ & $178(58.7)$ & $25(8.3)$ & 2.74 & $4^{\text {th }}$ \\
\hline Property that has Balcony & $3(1.0)$ & $128(42.2)$ & $162(53.5)$ & $10(3.3)$ & 2.59 & $5^{\text {th }}$ \\
\hline Property with large floor area & $16(5.3)$ & $144(47.5)$ & $114(37.6)$ & $29(9.6)$ & 2.51 & $6^{\text {th }}$ \\
\hline Property with Good ceiling & --- & $65(21.5)$ & $231(76.2)$ & $7(2.3)$ & 2.81 & $3^{\text {rd }}$ \\
\hline Property with cross Ventilation & $3(1.0)$ & $38(12.5)$ & $240(79.2)$ & $22(7.3)$ & 2.93 & $2^{\text {nd }}$ \\
\hline Property with good water quality & $5(1.7)$ & $37(12.2)$ & $40(13.2)$ & $221(72.9)$ & 3.57 & $1^{\text {st }}$ \\
\hline Property with Good Waste Disposal & $39(12.9)$ & $149(49.2)$ & $84(27.7)$ & $31(10.2)$ & 2.35 & $7^{\text {th }}$ \\
\hline
\end{tabular}

may include lack of finance, proximity to other activities and social inclination among others. The next section will evaluate level of resident's satisfaction with the quality of housing units in the study area.

\section{B. Residents Perceived Satisfaction with Housing Condition in the Study Area}

As evident in Figure 1, there seems to be a close in the view of the respondents on their satisfaction with the overall housing condition of the study area. This is as about $46 \%$ of the respondents are not satisfied with the condition of their housing units while a contrary view was made by a close proportion of $54 \%$. Meanwhile, an inquiry into each dimension of the housing condition reveals that except safety $(86 \%)$ and wall and roof condition (73\%) that respondents are highly satisfied with, there is a near consensus on the satisfaction level of residents with other measured environmental parameters. For instance, $50 \%$ of the respondents are satisfied with access, while an equal proportion is dissatisfied. Similarly, $49 \%$ and $43 \%$ are satisfied with cross ventilation and noise level in the area respectively while a close percentage of $51 \%$ and $57 \%$ are dissatisfied. Meanwhile, a high proportion $(65 \%)$ of respondents is dissatisfied with water and sanitation in the area. From the foregoing, it can be surmised that the wall and roof of the housing units in the estate could have either been effectively done as well as properly managed. The almost even results observed for cross ventilation, access, and the evidently reported dissatisfaction of respondents with water and sanitation raised concern about the environmental variables. This reported environmental conditions could have influenced the rental value of the housing units.

\section{Willingness to pay for Healthy Building Parameters}

In this section, the perception of respondents with reference to their willingness to pay for upgraded housing with healthy environmental features was evaluated. This was done using a four-point factor scale. Those willing to pay \#5,000- \#10,000 more per annum were rated 1point, in that order, up to 4-pointslikert for those willing to pay \#30,000 and above more annually. The hierarchical order of the factors was now computed (ranking) in order in which they influence their willingness to pay (WTP). Seven features were considered, and they are; wide and multiple windows, large floor area, good ceiling, cross ventilation, good water quality and good waste disposal. 
As evidenced in Table 2, the study ranked the response on the factors in hierarchical order of average score on the WTP. Observing the table critically, good water quality is highly ranked above all other attributes with a mean score of above 3.5.Hence, respondents are willing to pay for good water source than any other factor, and as such may imply that the first factor that respondents consider for their housing units is water source. Next to this is cross-ventilation, (2.93) good- ceiling (2.81), wide and multiple windows, balcony(2.59), large floor area (2.51) and the least importantfactor that residents are willing to pay for isa good waste disposal system (2.35).

\section{Conclusion and Recommendations}

After examining the housing condition in Jakande Estate, Nigeria and the willingness of its residents to pay for healthy features, it was evident that the rental value of residential property could be determined by the presence or absence of good quality building parameters. These parameters in their order of importance are source of water, cross-ventilation and multiple windows, condition of property (ceiling and roofs),good environmental condition, and neighbourhood security.

It is therefore recommended that to improve the overall housing condition in the area as well asadd value to residential properties in the estate, developers are encouraged to rehabilitate the existingbuildings through the provision of boreholes for portable watersupply. Such boreholes could be centralised to avoid unnecessary replication of boreholes which can stress the earth crust. Also, sanitation should be improved in the area through the designation of waste collection centre and employment of community sanitation workers.
Conclusively, management of housing estate, though owned by the government, is more tilted towards community participation, hence such should be encouraged in the estate.

\section{References}

[1] Ridke,R.G. and Henning,J.A., "The Determinants of Residential Property Values with Special Reference to Air pollution". Rev.Econ.Statist.1967,pp.246-257

[2] Stegman, M.A., "Accessibility Models and Residential location", Journal of the American Institute of Planners,Vol. 35, No.1, 1969, 22-29. doi;10.1080/01944366908977823

[3] Evans, J., Hyndman, S., Stewart-Brown, S. Smith, D. and Petersen, S., "An Epidemiological Study of the Relative Importance of Damp Housing in Relation to Adult Health", J Epidemiol Community Health, Vol. 54, 2000, pp 677-686.

[4] Okewole,I.A and Aribigbola, "Innovations and sustainability in Housing Policy Conception and Implementation in Nigeria". In:The Built Environment: Innovation Policy and Sustainable Development., 2006, pp. 414-420.

[5] Chau, K.W. and Ng, F.F., "The Effects Of Improvement in Public Transportation Capacity on Residential Price Gradient in Hong Kong”, Journal of PropertyV aluatione Investment, Vol. 16, No. 4, 1998, pp. 397-410.

[6] Chau, K.W., Yiu, C.Y., Wong, S.K and LAI, L.W.C., "Hedonic Price Modelling of Environmental Attribute: A Review of the Literature and a Hong Kong Case Study" In lai, I.W.C. and Lorne, F. (Eds), Understanding and Implementing Sustainable Development, 2003.

[7] Best, R., "Health Inequalities: The Place of Housing". In: Inequalities in health: the evidence. The evidence presented to the Independent Inquiry into Inequalities in Health, chaired by Sir Donald Acheson, Gordon, D., Shaw, M., Dorling, D. \& Davey Smith, G. (eds), The Policy Press, Bristol,1999. 
[8] World Health Organization, "The World Health Report 1997. Conquering Suffering Enriching Humanity". Report of the Director-General, Geneva, 1997.

[9] Rodriguez, M. and Sirmans, C.F., "Quantifying the Value of a View in Single Family Housing Market", The appraisal Journal, Vol. 62, No. 4.

[10]Chau,K.W., "Assessing The Health and Hygiene Performance of Apartment Buildings Facilities", Vol.22, No.3/4, 2004, pp 58-69.

[11]Fullilove, M.T. and Fullilove, R.E., "What's Housing Got To Do With It? " Am J Public Health, 90(2), 2000, pp 183-184.s

[12]Jelili M.O, Olanrewaju S.O and Odunola O.O., "Spatial Distribution And Land Useplanning of Informal Automobile Workshops in Osogbo, Nigeria". Ethiopian Journal of Environmental Studies and Management. Vol 10, No. 1, 2017, pp 112-124.

[13]Boyle, M.A. and Kiel, K.A.(2001), "A Survey of House Price Hedonic Studies of The Impact of Environmental Externalities", Journal of Real Estate Literature, Vol.9, No.2, 2001, pp.117-44. 